\title{
THE FINAL SETTING OF THE GOLDEN AGE OF THE PRESS IN THE WORLD: THE CANARY ISLANDS DURING THE SPANISH REPUBLIC
}

\author{
Julio Antonio Yanes Mesa \\ (Universidad de La Laguna) \\ jayanes@ull.es
}

\begin{abstract}
This article addresses the evolution of the press during the period between the world wars (1914-1945) in an exceptional European micro-space, the diminutive and distant Spanish archipelago of the Canary Islands. The account given here reveals that, although Canary Islands newspapers followed in the wake of others published in the leading enclaves of the Western world, they were late in doing so and did so in an unusual manner and in negligible numbers, due to socioeconomic backwardness, isolation, and a minimal readership and market for advertising. The aim of this paper is to integrate the communicative reality studied into the world history of journalism, as advocated by the latest tendencies in history-writing, in order to further knowledge of events that occurred in more developed areas and their subsequent influence on outlying, marginal regions, whose response was more modest and belated, owing to greater contextual limitations.
\end{abstract}

Keywords: World history of journalism, Canary Islands, early information firms, Golden Age of the press, Spanish Second Republic.

Resumen: En el presente artículo abordamos la evolución de la prensa de los años de entreguerras (1914-1945) en un microespacio europeo tan singular, por su pequeñez y lejanía, como el archipiélago español de las Islas Canarias. La exposición demuestra que, aunque los periódicos canarios siguieron la estela marcada previamente por los editados en los enclaves punteros del mundo occidental, lo hicieron con demora, de manera singular y a unos niveles cuantitativos ínfimos, por el retraso socioeconómico, el aislamiento y la reducción del mercado lector y publicitario. Con esta aportación, pretendemos incorporar la realidad comunicativa estudiada a la Historia del Periodismo Universal para, tal y como propugnan las últimas corrientes historiográficas, enriquecer los conocimientos de los procesos acontecidos en las áreas más desarrolladas a la vista del eco de éstos en los espacios periféricos y marginales, donde cristalizaron a niveles mucho más modestos y tardíos por las mayores limitaciones contextuales.

Palabras clave: Historia Universal del Periodismo, Islas Canarias, primeras empresas informativas, edad de oro de la prensa, II República Española. 
The final setting of the golden age of the press in the world:

The Canary islands during the spanish republic

\section{INTRODUCTION}

T

wo thousand and nine will mark 75 years since the appearance of Le Journal by Georges Weill, now a classic and one of whose main contributions was to pinpoint the "Golden Age" of the press in the three decades leading up to the outbreak of World War I (Weill, 1994: 173-182). Indeed, the study brought to light the unrepeatable circumstance in which newspapers, after acquiring an autonomous business structure as a result of the socioeconomic improvements of the time, were able to carry out their informative work with an independence previously denied them, and luckier still, when radio had not yet made its appearance. But the field of observation was limited to New York, London, Paris and other leading enclaves of the Western world, influenced by the historiographic parameters of the time and the lack of prior territorial studies. Accordingly, the communicative reality in which most of humanity was immersed remained well hidden. New historiographic perspectives on the contribution by Weill, Giuliano Gaeta, Pierre Albert, Anthony Smith and others, and which generally call for history to be more closely linked with personal experience (Iggers, 1998: 59-112), have led to an influx of works focussing on very specific geographical locations, which increasingly allow for greater knowledge of the territorial differences arising from different levels of socioeconomic development. So much so that, after 1920, when newspapers lost the monopoly on information in the most advanced areas after radio was introduced, other places had yet to discover the "Golden Age" of the press, a situation that many never actually enjoyed because audiovisual media reached them before editors could gain independence from their patrons.

The following lines recreate the arrival of the "Golden Age" of the press in an isolated micro-space of around $7,500 \mathrm{~km}^{2}$-the Spanish archipelago of the Canary Islands - in the 1930s, practically half a century after the period signalled by Weill, when radio was widespread throughout the world and television was making inroads in England, Germany and the United States.

\section{THE EXCEPTIONAL LOCATION OF THE CANARY ISLANDS IN THE WEST- ERN CONTEXT}

The one factor that has conditioned the history of the Canary Islands since their incorporation into the Western world in the late fifteenth century is their location between latitudes $27^{\circ}, 30^{\prime}$ and $29^{\circ}, 30^{\prime}$ in the northern hemisphere, over a thousand kilometres from the Iberian Peninsula and a hundred miles off the west coast of North Africa, en route to the New World discovered by Christopher Columbus. Indeed, aside from becoming an obligatory port of call for ships crossing the Atlantic until well into the twentieth century, the Canaries made the most of their remarkable location to satisfy the short-term demands of Western Europe, particularly England. A series of sub-tropical agricultural products provided the wherewithal to import items that any far-off, fragmented land with meagre resources is unable to produce. Until the 1960s, when mass tourism began to fulfil 
this role to the detriment of agriculture, island life revolved around the production cycle and the commercialization of crops for export at all times. Equally important were the harbour activities arising from exporting consignments to the old world, and from imports and service provision for passing vessels. During the golden years of the press in the leading areas of the Western world, and until the arrival of mass tourism, the external sector of the Canary Islands economy was organised around the production of bananas, tomatoes and early potatoes, whose main destination was the British market (Macías \& Rodríguez, 1995: 369-398).

At that time, apart from the enslavement arising from dependence on the exterior, the economic model of the islands had generated a social structure headed by an endogamic agrarian elite of large producers based inland and by a much more dynamic sector, open to external influences, which was made up of merchants and export agents located at leading ports. At the disposal of both groups were the working classes. The absence of a middle class that would not develop until the arrival of mass tourism several decades later provided little cushioning effect. An excess of manpower, particularly during times of drought and critical moments for the external sector, meant that the only escape for the lower classes was emigration to America. In such a precarious setting, the situation of the press in the Canaries was highly remarkable. Apart from its logical backwardness when compared to the largest cities in Spain, and even more so, to the leading Western powers, where it was enjoying a "Golden Age", the local press went about its daily business isolated from the outside world every time maritime links delayed the arrival of the most important Spanish newspapers by several days.

In those years, the Canary Islands were so different to the global village in which most of humanity is currently submerged. Straggling behind and isolated from the rest of Spain and from the Western world in general, this background explains the extraordinary development of the information system in the islands. Our exposition is the result of a whole of partials studies focused on a line of investigation opened more than two decades ago. With that line we seek to build up, little by little, a History of the journalism on the Canary Islands from international perspectives.

\section{THE CANARY ISLANDS PRESS ON THE EVE OF THE GREAT WAR}

When the outbreak of the Great War was imminent, the Canary Islands housed a population of fewer than half a million inhabitants. Around $30 \%$ lived in the capital cities of the two largest islands, Santa Cruz de Tenerife and Gran Canaria, home of the two most important newspapers in the archipelago. At that time, ever increasing port traffic and exports of bananas, tomatoes and early potatoes to England led to the introduction of services that were already widespread in leading European and American cities at the end of the previous century (electricity, the telephone, and the tram-the latter only in Santa Cruz de Tenerife), all of which were closely linked to the entrepreneurial development of the press. These signs 
The final setting of the golden age of the press in the world:

The Canary islands during the spanish republic

of modernization, however, were confined to the central areas of the hinterland around the two main island ports, while the rest of the island territory, where over $70 \%$ of the population lived, continued anchored to a traditional agricultural way of life.

Consistent with the insignificance, isolation and socioeconomic backwardness of the environment in which it was created, the most characteristic feature of the local press was the assignation of the principal newspapers to the various political factions of the moment-in other words, old-style politicization. Poor standards of living, an illiteracy rate of over $65 \%$, dire internal and external communications, brutal tyranny by local political bosses and underdevelopment explain why journalism in the Canaries was still submerged in ideologies typical of the nineteenth century and far removed from the informative mission already being enjoyed in Madrid and Barcelona (Seoane \& Sáiz, 1996: 321-350, 397454), which were both in the vanguard of Spanish information systems, some of the most archaic and heterogenous in Europe. The reason for such backwardness was simple: since the islands were not yet able to house independent information companies, editors were forced to seek the support of a group or social sector in order to launch their newspapers with a minimum guarantee of continuity. In the face of the paltry cultural and commercial world available, political parties offered the best option.

The communicative dynamics of the press in that archaic, miniscule and isolated setting were exceedingly remarkable. Indeed, the survival of each newspaper was guaranteed by subscriptions made by partisans and, to a lesser extent, by their commitment to advertising in its pages, despite the fact that it was not yet commercially profitable for island businesses to do so. In exchange for such unconditional economic support, political forces acquired an organ for internal communication, more for the purpose of uniting ranks rather than for creating propaganda to recruit new followers from among potential readers because of the barriers put in place by local political bosses and other archaisms. With such limitations, editors who dared produce a newspaper with the intention of providing independent information, that is, without ensuring their readership beforehand in exchange for some concession or other, would fall into a vicious circle. If they bravely took a stand against local issues, they would face the fury of the followers of the denounced. And if they avoided the thorniest questions in an attempt to elude such problems, they would hinder sales even more because of a lack of interest in the information supplied.

Aside from its ideologization, the other most obvious features of journalism in the Canary Islands before the war were its highly fragmented nature, an incessant coming and going of newspapers, an extremely low print run, limited geographical circulation and rivalry between the island capitals of Tenerife and Gran Canaria in their eagerness to win over the region's decision-making bodies. Such features stemmed from a series of highly diverse factors that accompanied the hindrances mentioned above, such as low production costs, which, for leading newspapers, 
meant printing two sheets on a flat machine; the permissive Spanish printing law of 1883 , which did not stipulate censorship or any prior deposit for addressing political matters; and the inconsistencies of regional political formations whose dynamics were marked by social elitism, an ideological void, internal dissent and tergiversation. The result was an information system split up into numerous inconstant headlines, a daily circulation of a thousand copies at best and limited to tiny areas because of the disjointed market resulting from a fragmented territory divided into seven islands, and above all the divisions and disagreements arising from the fierce struggle between the region's two capital cities.

Where content was concerned, the chief characteristics of this anachronistic press included focussing information on local matters, fiery political disputes, and closely linked to the latter, an overabundance of praise and insult aimed at supporters and adversaries, respectively. Against this background, it was possible to perceive several features that accentuated the personality of the local compared to the national press. Close commercial ties with England and incipient health tourism in Puerto de la Cruz (Tenerife) revealed an Anglo-Saxon influence that was visible in the format of several newspapers, advertisements and notices in English in Diario de Tenerife (1886-1917) and even the publication of The Tenerife News (1891), the first newspaper to be edited entirely in a foreign language in Spain. The same could be said about the privileged position that most headlines afforded, for similar economic reasons, to two specific issues such as harbour activities and Latin American matters, particularly regarding Cuba, Venezuela, Argentina and Uruguay, where Canary Islands emigrés had founded numerous newspapers. In this unusual setting, the more polished broadsheets occupied a dominant position (Yanes, 2003: 271-370) since they paid heed to the social sensibilities of their readers, providing more veracious and up-to-date contents that met the demands of the learned minority who merely wanted to be informed.

Looking through the most important headlines of the region's two island capitals, these specific characteristics are easily identifiable in the local newspapers of the time. Indeed, they all revealed an easily detectable political ideology, since most openly stated their undertaking in the subtitle, exhibiting, with several subtle differences, a rudimentary composition of limited attraction for the modern reader. The information offered barely covered four pages; the composition was based on lengthy texts preceded by monotonous, miniscule headlines, normally less than a column in length, and was sporadically illustrated. Outside information took the form of a telegram sent at the end of the previous day by the correspondent in Madrid and exaggerated by the extended practice of local editors who proceeded to pad it out with their own words. These archaisms were slightly attenuated in La Prensa (1910-1939), Santa Cruz de Tenerife and La Provincia (1911...), Las Palmas de Gran Canaria, which, given their synchronisation with social demands in their areas of coverage, explains their dominance in the west and east of the region, respectively. 


\section{THE IMPACT OF A TEMPORARY FACTOR: AN INTEREST IN NEWS PRO- VOKED BY THE FIRST WORLD WAR (1914-1918)}

With the outbreak of the Great War in Europe in the summer of 1914, journalism in the Canary Islands underwent a sudden and radical transformation. This was triggered by information that emerged from the Old World, arousing the islanders' interest in newspapers at a time when they were the only available means of information. As if war were not enough in itself, both adversaries set in motion propaganda campaigns to favour their respective causes and news soon began to reach the Canaries in quantities, and at a price and speed hitherto unknown. Radiotelegraphy stations installed in 1911 on the two main islands brought wireless telegraphy, previously beyond the scope of the sector, and a torrent of outside information, obviously within the limitations of the period, thereby rendering the pre-war short telegram obsolete.

At the same time, the communities of foreign nationals settled in the islands supplied informative accounts that were readily accepted by local newspapers, however impartial, on the basis that they were free. Editors then re-wrote the accounts with details gathered in one way or another, so as to prolong their readership's reading time. Since the newspapers came out in favour of one side or the other (the Allies or the Germans), as indeed did mainland Spanish and island society, the outcome of the military campaigns generated highly contradictory versions, which often resulted in deep clashes in the press. In the din of such controversy, traditional internal and political disputes faded into oblivion, and local information was relegated to the inside pages.

The new direction boosted circulation and forced many newspapers to produce special evening editions. It also caused a breakdown of the readership's traditional ideological compartmentation as more and more readers based their purchase decision on information quality. In these circumstances, editors who best addressed new market demands monopolized the modest increase-since illiteracy rates were high-in the numbers of buyers, when the illiterate majority had to conform to attending typical collective readings improvised at inns and barbershops. La Prensa, in the west (Yanes, 1995: 95-153), and La Provincia, in the east, faced the situation with considerable success, which enabled them to consolidate their leadership in their respective areas of coverage.

But the war did not just bring satisfaction for the region's newspapers. Over the years, the Canary Islands became submerged in a growing economic crisis influenced by the gradual slowing down of harbour activities and the disappearance of fruit exports to England. The situation became dramatic as from 1916, when incursions by German submarines frightened off the few foreign steamships that still put into Canary Islands ports. The effects of the crisis reached the press through considerably higher production costs such as the price of a ream of paper that increased five fold in four years, sales contraction and a reduction in the modest income from advertising. The postwar years were equally tough. Added to the wait imposed by the slow reestablishment of bilateral relations between world 
powers on the international scene was the aftermath of a lengthy drought in the islands that ruined internal subsistence production (Yanes, 1997: 31-38).

A direct result of the hardships endured was the closure of the vast majority of newspapers either because they lacked strong backing from their supporters or because they had been unable to increase their readership during the information break at the start of war. On that devastating scene, La Prensa and La Provincia were, once again, the only broadsheets to escape the situation unscathed. And they did so by capturing the bulk of the few surviving readers and advertisers, and by consolidating their dominating position in their respective areas of coverage. While maintaining most of their basic support through informational merit, they had gained a readership whose social make-up and interests were far more heterogeneous. Consequently, when times grew hard, other readers joined their ranks after the closure of the majority of their competitors.

\section{THE IMPACT OF A STRUCTURAL FACTOR: SOCIOECONOMIC DEVELOP- MENT IN THE SWINGING TWENTIES}

When the tail-end of the crisis had passed, the Canary Islands press took advantage of the decade's economic bonanza and set about modernizing financial, technological and informational aspects. Consequently, the loss of the opportunity to attract new readers as a result of the war was greatly compensated by the structural improvements gradually introduced with the growth of the regional economy in the swinging twenties. The establishment of the dictatorship by General Primo de Rivera in September 1923 did not hamper this process. Though it coerced newspaper activities, by way of compensation, it did put an end to the traditional dynamics of the sector by eradicating partisan polemics and weakening political formations.

The modernization of the sector was reflected in the format and contents of the region's leading newspapers, La Prensa and La Provincia, whose editors ably adapted their editorial lines to the new times and capitalized on them. As the 1920s rolled by, both newspapers increased their informational coverage from 4 to 6 and then to 8 pages, improving composition, enlarging headlines, distributing contents into more stable sections, and introducing photography as an everyday feature. At the same time, both broadsheets expanded their editorial lines to include national and international affairs, devoted specialist pages to specific segments of their potential readership and paid considerably more attention to sports, cinema, entertainment and mass culture, which was taking its first tardy steps in the region. All for the purpose of increasing numbers in a readers and advertisers' market which, as a result of the socioeconomic improvements of the period, was at the height of expansion.

Underlying the process was the economic growth resulting from the rise of fruit exports to England and particularly the urban development of the two island capitals, home to the main markets of the most important broadsheets. These 
The final setting of the golden age of the press in the world: The Canary islands during the spanish republic

years also witnessed improvements to communications, namely, the beginning of motor car traffic in the islands, which accordingly led to an expansion in the precarious network of roads and tracks, smoother internal and external maritime and telegraphic links, telephone connections between most island towns and, at the end of the decade, with mainland Spain, Europe and eventually America. In the midst of this boom, the two factors that most directly breathed new life into local journalism were increasing numbers of potential readers, due to a rise in the standard of living and a drop in illiteracy rates to below $50 \%$, and the development of advertising as a profitable commercial resource in a setting in which mass culture was just making an appearance. Over the years, both factors surprisingly colluded to slowly disrupt the basis on which Canary Islands newspapers had traditionally pivoted.

Indeed, the continual rise in the numbers of readers as a direct result of improved living standards was also reflected in the numbers of those who, instead of acquiring a newspaper to support party members as had been the majority custom until then, exercised their freedom of choice in view of the information on offer, as more and more citizens sought to keep abreast of world events. Furthermore, as businesses noticed the growing influence of advertising on the market, advertisers contracted spots in newspapers with the highest circulation, without the political commitments of previous years, as they now had the chance to turn the outlay to a profit. Consequently, both factors gave editors the opportunity to leave behind the diminished ideological circles of traditional dissemination, weakened by Primo de Rivera's dictatorship, simply by offering a good information service about current affairs and by introducing timely commercial strategies, thus following in the wake of the press in the most developed areas of the Western world in the last two decades of the nineteenth century.

Technological landmarks included the rotary press that was brought to the Canary Islands by La Provincia in 1923 and a year later by La Prensa, followed by typesetters, stereotypy and photogravure that revolutionized the sector's workshops and infrastructure. And on an informational level, the receipt of models forged by the new journalism (Schudson, 1997: 203-212), inspired by innovations introduced in 1883 by Joseph Pulitzer in New York, which had existed in the Western world's leading cities from the late nineteenth century until the outbreak of the Great War. However, in the Canary Islands, and indeed in the rest of Spain (Álvarez, 1989), persistent illiteracy among the working classes and limited socioeconomic development meant that the popular press had little room to manoeuvre.

\section{THE SPANISH SECOND REPUBLIC: THE GOLDEN AGE OF THE PRESS IN THE CANARY ISLANDS}

After the fall of Primo de Rivera's dictatorship and the proclamation of the Spanish Second Republic in April 1931, freedom was regained, thus enabling journalism 
in the Canaries to culminate the transition begun in the swinging twenties from an ideological to an informational stage. Underlying this mutation was the financial investment structure in leading newspapers of the time, which, in clear opposition to the pre-war period, now obtained most of their income from advertising, despite the fact that sales had multiplied by five. Though qualitatively similar to the experiences of leading newspapers in the Western world in the late nineteenth century, the consequences of the process were quantitatively negligible and consistent with the insignificance of the island setting. Indeed, while the top mass media in New York, London and Paris had achieved a circulation of millions, the leading broadsheets in the Canaries had to content themselves with just over seven thousand copies. But, in the precarious business fabric of the islands, these figures were enough to capitalize on the sector and generate independent media companies, able to adopt editorial lines independent of the guidelines put forward by political factions. In all other respects, the modernization of the sector entailed a return to the fragmented nature of the past, shielded by the overwhelming dominance and concentration of the top newspapers in the upwardly mobile urban centres of Santa Cruz de Tenerife and Las Palmas de Gran Canaria.

As a result, the information system in the Canary Islands in the 1930s was enjoying the exceptional circumstances described by Georges Weill at the time as the "Golden Age" of the press since, after breaking away from ideological ties, the region's newspapers freely monopolized information services with barely any competition from the radio (Garitaonaindía, 1988: 51-143). Although Hertzian waves were already circulating the Western world (Albert \& Tudesqu, 2001: 35-54), they did not reach the Canaries until 1934, when two low-power radio stations were set up in Santa Cruz de Tenerife and Las Palmas de Gran Canaria. And even then the dynamics of the region's information system remained the same. Both radio stations could only feature music programmes because of limited broadcasting times and low coverage, due to the short signal range and mountainous terrain. In addition, audiences were reduced to a few elite listeners because receivers were few and far between. Accordingly, the radio was no match for the press when providing a news service. In short, the Canary Islands press had the chance to relish a privileged situation with almost fifty years' delay compared to New York, London, Paris and other important cities in the West. The region became the final setting for a remarkable period in world information.

The controversial Spanish Second Republic in the midst of the menacing international problems unleashed by the Fascists and the Wall Street crash in 1929 (Yanes, 1999) was the setting (very similar to that woven by imperialist tensions prior to World War I for the leading press in the West) in which journalism in the Canaries lived its "Golden Age". Indeed, La Prensa and La Provincia had become independent newspaper companies, employing a staff of around 20, and two other broadsheets had evolved in their shadow: La Tarde (1927-1982) in Santa Cruz de Tenerife and Diario de Las Palmas (1893-1939 and 1953-2000) in Gran Canaria. The former were morning and the latter evening newspapers, and they kept the growing population informed throughout the day during those years of unrest. By 
The final setting of the golden age of the press in the world:

The Canary islands during the spanish republic

satisfying such demand, all four newspapers attained economic stability without sacrificing their editorial lines to any political party as before. As if these incentives were not enough, editors multiplied the impact of the news by adopting new journalism strategies introduced at the end of the previous century, while attempting to satisfy the demands of all sectors of the population by paying more attention to the growing mass culture.

Added to the internal and external factors that boosted the island press, the distance from the Iberian Peninsula and the sea, which delayed the arrival of the Madrid newspapers as they could not be sent by train, preserved the tiny island readership to the benefit of local companies. Spanish and foreign Hertzian waves from the exterior provided no competition whatsoever. Radio receivers were few and far between and reception was difficult, which accentuated the nature of the islands as a kind of special reserve for the home-grown press. In short, a series of very different factors led to a "Golden Age" for the press in the Canary Islands during the Spanish Second Republic, when information systems in other parts of the world were already dominated by the radio (Sterling \& Kittross, 1997: 309316). Interestingly, the events that brought an end to such a privileged situation for the press in the Canaries, the Spanish Civil War (1936-1939) and World War II (1939-1945), when General Franco's dictatorship promoted and began using the islands' radio stations for propaganda, are also markedly similar to those occurring in the majority of the most advanced parts of the Western world 20 years beforehand, namely, the First World War (1914-1918).

\section{BIBLIOGRAPHICAL REFERENCES}

ALBeRT, P. (1970) : Histoire de la Presse. Paris: Presses Universitaires de France.

ALBERT, P.; y TUDESQU, A. J. (2001): Historia de la radio y la televisión. México: Fondo de Cultura Económica (2a edición en español).

ALMUIÑA FERNÁNDEZ, C. (1977): La Prensa Vallisoletana durante el siglo XIX, 18081894. Valladolid: Diputación Provincial.

ÁlVAREZ FERNÁNDEZ, J. T. (ed). (1989): Historia de los medios de comunicación social en España. Periodismo, imagen y publicidad, 1900-1990. Barcelona: Editorial Ariel.

BÈTHENCOURT MASSIEU, A. (ed.) (1995): Historia de Canarias. Las Palmas: Cabildo de Gran Canarias.

DESVOIS, J. M. (1977): La Prensa en España, 1900-1931. Madrid: Siglo XXI.

GAETA, G. (1966): Storia del giornalismo. Milán: Francesco Vallardi.

GARITAONAINDÍA GARNACHO, C. (1988): La radio en España (1923-1939). De altavoz musical a arma de propaganda. Bilbao: Universidad del País Vasco.

GÓMEZ MOMPART, J. LL.; y MARÍN OTTO, E. (1999): Historia del Periodismo Universal. Madrid: Editorial Síntesis.

HOBSBAWM, E. (1987): The Age of Empire, 1875-1914. London: Weidenfeld and Nicolson. 
IGGERS, G. (1998): La ciencia histórica en el siglo XX. Barcelona: Idea Universitaria.

MACÍAS HERNÁNDEZ, A; y RODRÍGUEZ MARTíN, J. A.: La economía contemporánea, 1820-1990. En BÈTHENCOURT MASSIEU, A. (1995): Historia de Canarias. Las Palmas: Cabildo de Gran Canaria, pp. 369-398.

SCHUDSON, M.: El nuevo periodismo. En CROWLEY, D.; y HEYEK, P. (1997): La COmunicación en la Historia. Tecnología, cultura, sociedad. Barcelona: Bosch, pp. 203-212.

SEOANE, M. C.; y SÁIZ, M. D. (1996): Historia del periodismo en España, 3. El siglo XX: 1898-1936. Madrid: Alianza Editorial.

SMITH, A. (1979): The Newspaper. An International History. London: Thames \& Thames.

STERLING, C.; y KITTROSS, J. M. La edad de oro de la programación. En CROWLEY, D.; y HEYEK, P. (1997): La comunicación en la Historia. Tecnología, cultura, sociedad. Barcelona: Bosch, pp. 309-316.

SUÁREZ BOSA, M. (1995): Economía, sociedad y relaciones laborales en Canarias en el período de entreguerras. Las Palmas: Universidad de Las Palmas de Gran Canaria.

SWANBERG, W. A. (1967): Pulitzer. New York: Charles Scribner's Sons.

VÁZQUEZ MONTALBÁN, M. (2000): Historia y comunicación social. Barcelona: Mondadori (reedición ampliada de la de 1980).

WEILL, G. (1934): Le journal. Origines, évolution et rôle de la Presse périodique. Paris: La Renaissance du Livre.

- (1994): El periódico. Orígenes, evolución y función de la prensa periódica. Méjico: Uteha (2 $2^{a}$ reimpresión).

WILLIAMS, R. (ed.): Historia de la comunicación, 2 vols. Barcelona: Bosch, 1992.

YANES MESA, J. A. Leoncio Rodríguez y 'La Prensa': una página del periodismo canario. Santa Cruz de Tenerife: Cabildo de Tenerife, CajaCanarias \& Editorial Leoncio Rodríguez, 1995.

- (1997): Crisis económica y emigración en Canarias. El puerto de Santa Cruz de Tenerife durante la guerra europea, 1914-1918. Santa Cruz de Tenerife: CCPC.

- (1999): La Gran Depresión en Canarias. Un estudio con fuentes hemerográficas. Santa Cruz de Tenerife: CCPC.

- (2003): Historia del Periodismo Tinerfeño, 1758-1936. Una visión periférica de la Historia del Periodismo Español. Santa Cruz de Tenerife: CCPC.

- (2010): Los orígenes de la radiodifusión en Canarias. Radio Club Tenerife, 1934-1939.

Santa Cruz de Tenerife: Ediciones Baile del Sol [en prensa].

\section{NEWSPAPER REFERENCES}

Diario de Las Palmas (1893-1939 y 1953-2000), Gran Canaria.

Diario de Tenerife (1886-1917).

La Prensa (1910-1939) de Santa Cruz de Tenerife. 
La Provincia (1911...) de Las Palmas de Gran Canaria.

La Tarde (1927-1982) de Santa Cruz de Tenerife.

The Tenerife News (1891), Puerto de la Cruz, Tenerife.

\section{Breve semblanza biográfica del autor}

Julio Antonio Yanes Mesa es Doctor en Historia (1991) y en Ciencias de la Información (2000) por la Universidad de La Laguna, donde ejerce como Profesor Titular de Periodismo, especialidad en Historia de la Comunicación, de la Facultad de Ciencias de la Información. Su línea de investigación ha partido, desde el punto de vista geográfico, de las Islas Canarias, desde el cronológico, de los años de entreguerras (1914-1945) y, desde el documental, de las singulares fuentes hemerográficas isleñas, para luego ir, poco a poco, rebasando y diversificando tales ámbitos, conforme ha ido dando respuesta a los problemas planteados. Sobre tales bases, su producción historiográfica ha abordado temas tan diversos como el periodismo, la emigración a Cuba, la vida cotidiana, las reclutas militares, el problema del agua, las migraciones interiores, la economía o la radiodifusión.

(Recibido el 08-04-2009, aceptado el 11-03-2010) 